AIDS

\title{
Academies demand urgent public education
}

\section{Washington}

An immediate and massive public education campaign is needed to slow the spread of acquired immune deficiency syndrome (AIDS), according to a report released last week by the Institute of Medicine (IOM) and the National Academy of Sciences*. In addition to the $\$ 1,000$ million a year required to pay for this educational campaign, the report also urges that support for AIDS research should be increased to $\$ 1,000$ million a year by 1990 . Without decisive action, IOM president Samuel Thier says, the epidemic may "snowball into an even greater catastrophe".

Following it annual meeting in 1985, the Institute of Medicine determined that it should provide direction for the US effort to combat AIDS. With Thier as its new

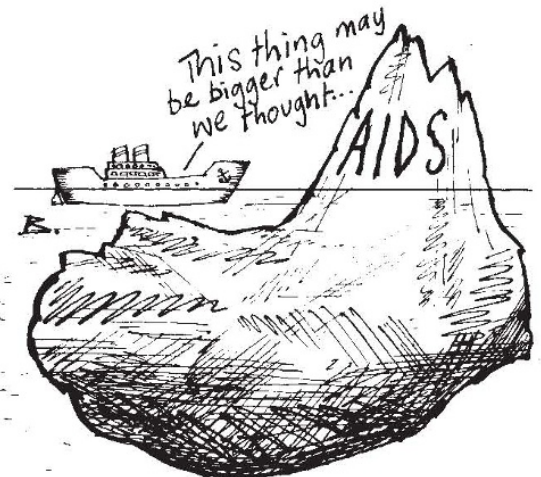

president, the institute together with the academy made the development of recommendations for dealing with the AIDS epidemic a priority. Last week's 374-page document was produced in slightly more than seven months. David Baltimore of the Whitehead Institute and Sheldon Wolff of Tufts University Medical School co-chaired the panels responsible.

Although the report praises government support for research on the biology of the AIDS virus (HIV, or human immunodeficiency virus), the report is critical of the government's effort in public health. In particular, federal educational efforts are dubbed "woefully inadequate". Until an effective vaccine is developed, Wolff says that educating the public is the best hope for curbing the disease. The report reckons an effective campaign involving all levels of government as well as industry and private organizations will cost about $\$ 1,000$ million a year.

Almost as if anticipating the IOM report's criticism, Surgeon General C.

- Confronting AIDS: Directions for public health, health care and research. National Academy Press, Washington, DC, 1986.
Everett Koop called for an increased educational effort in a report released one week before the IOM report. Declaring that "the silence must end", Koop says it is no longer possible "to sidestep frank, open discussions about sexual practices homosexual and heterosexual". Education must be extended to prepubescent children as well as to their parents, according to the Koop report.

Wolff describes the surgeon general's report as "clearly a step in the right direction". Both reports urge the use of condoms for men who are not certain if their partners are infected with HIV.

A vexing problem in determining how best to orchestrate an educational campaign against the spread of AIDS is the lack of information about sexual practices. Baltimore suggests that a significant portion of new research money should go to social science research in that area. Sexual intercourse remains the most common means of transmitting HIV. Although the disease primarily afflicts homosexuals, the Public Health Service estimates that heterosexual transmission will account for 10 per cent of new cases by 1991 .

As well as increased education, the report makes several specific recommendations about new public health efforts that should be attempted. As non-sexual transmission of AIDS occurs primarily through sharing of needles used for injection of intravenous drugs, the government should investigate the possibility of providing clean needles free of charge to users of illegal drugs. In strictly financial terms, the report says it is cheaper to treat a drug addict than an AIDS patient.

The report also calls for increased surveillance for both AIDS and AIDSrelated complex (ARC) cases, and voluntary testing of serological status for individuals who may have been exposed to the virus. The report declares that mandatory blood tests are inappropriate in most cases, the armed forces being a notable exception. Calling AIDS an international problem, the IOM report urges the United States to spend $\$ 50$ million a year on efforts to control the disease throughout the world.

The report recommends that a new National AIDS Commission be established to coordinate federal efforts in combating AIDS. But Baltimore does not see this office as playing a role in directing research. He says that research proposals initiated by investigators make the best use of scientific talent in learning more about HIV, but that a directed approach would be appropriate for a vaccine development project.

Federal funding for AIDS research has been nearly doubling in recent years. In 1984 , the government spent just over $\$ 61$ million on AIDS research. For 1987, that figure will jump to $\$ 410$ million. Gary Noble, now coordinating AIDS activities for the Public Health Service, will not speculate whether that rate of increase will be sustained. Noble agrees in principle with many of the IOM report's conclusions, but says new therapeutics or unexpected discoveries about HIV could change matters.

By 1991 the Public Health Service estimates there will be 270,000 cases of AIDS in the United States. There are already an estimated 1.5 million people infected with HIV. Academy president Frank Press says there is a need for a "national strategy to respond to a national crisis". Thier hopes the reports will mark the "turning point in the nation's approach to AIDS".

Joseph Palca

\section{AIDS drug test}

SHROUded by a veil of patent secrecy, an antiviral agent that is claimed to have more laboratory activity against the AIDS (acquired immune deficiency syndrome) virus than other anti virals is about to undergo animal toxicity tests in Britain. Porton International, the company that is developing the drug, hopes that it will pass the toxicity tests and can rapidly be tested by patients, using the US Food and Drug Administration's special fast-track procedure for potential AIDS drugs.

Porton will not, however, reveal anything of the chemical nature of the drug, which is named human immune virus antiviral. It is a natural substance extracted from a microorganism, and first emerged during a screening for antiviral compounds at the University of California (exactly where and by whom, Porton will also not reveal). Porton has acquired the rights to develop the drug which it is doing in collaboration with the Centre for Applied Microbiology and Research at Porton Down in Wiltshire, known for its expertise in the large-scale culture of microorganisms.

Peter Newmark

- THE British government, which this week set up a cabinet committee under Lord Whitelaw to look into the problems posed by AIDS is also under pressure to increase the publicity given to it and to consider a mail-drop to every home in the United Kingdom.

Critics of government strategy claim that the publicity campaign conducted in the British press since the spring has been a failure, as a high level of ignorance about the disease still prevails. Advertisements were placed in national newspapers this year, and AIDS publicity has been funded through a $£ 2.5$ million budget. 